\title{
Investigation of faecal archaeol as a biomarker for rumen methanogens
}

\section{F L Gill ${ }^{1}$, R D Pancost ${ }^{1}$ I D Bull ${ }^{1}$, E McGeough ${ }^{2}$, P O'Kiely $^{2}$, R J Dewhurst ${ }^{2}$}

${ }^{1}$ Organic Geochemistry Unit, University of Bristol, Cantock's Close, Bristol BS8 1TS, United Kingdom, ${ }^{2}$ Teagasc, Animal Production and Grassland Research Centre, Grange, Dunsany, Co. Meath, Ireland

Email: richard.dewhurst@teagasc.ie

Introduction There is growing interest in methane emission from ruminants, both because it represents a loss of up to 0.12 of gross energy and its role as a potent greenhouse gas. Research has been limited because chamber-based estimates of methane emission are both laborious and restricted to stall-fed animals, whilst the sulphur hexafluoride $\left(\mathrm{SF}_{6}\right)$ technique involves considerable experimental errors (Pinares-Patiño and Clark, 2008). Methane is produced by Archaea and the membranes of Archaea contain distinctive dialkyl glycerol ether lipids that have been used as biomarkers in a wide range of other sample types, including rice paddy soil and marine sediments. Recent studies have demonstrated the occurrence of the archaeal biomarker 2,3-diphytanyl-O-sn-glycerol (archaeol) in the faeces of ruminant and pseudo-ruminant species. The present study evaluated the potential to use the concentration of archaeol in bovine faeces as a marker for methane emission from diets with widely different forage/concentrate ratios, which were expected to generate divergent amounts of methane (Johnson and Johnson, 1995).

Materials and methods Twelve continental cross-bred steers $(541 \mathrm{~kg}(\mathrm{s.d} .=41.8))$ were blocked according to live weight and allocated at random to receive one of two dietary treatments based on grass silage and concentrates. Treatments were: (1) $5 \mathrm{~kg} / \mathrm{animal}$ daily of grass silage with ad libitum concentrates (diet CON), and (2) $3 \mathrm{~kg} /$ animal daily of concentrates with ad libitum grass silage (diet GS). Concentrates were based on mixtures of $(\mathrm{g} / \mathrm{kg}$ ) barley $(820$ or 460$)$, soybean meal (100 or 460), molasses (50), vegetable oil (10) and a mineral/vitamin premix (20) for the concentrates used for diets CON and GS, respectively. Individual feed intakes were recorded through Calan gates. Measurements of methane emission were taken from three animals per treatment after 5 and 16 weeks on these dietary treatments, using the $\mathrm{SF}_{6}$ technique (Lovett et al., 2003). At least three separate daily measurements were obtained from each steer (average 3.8/steer). Faecal samples were obtained per rectum over five days, stored at $-20^{\circ} \mathrm{C}$, then thawed, bulked and dried at $60^{\circ} \mathrm{C}$ (48 hours). Archaeol concentrations were measured in a faecal lipid extract. Faecal lipids were extracted and fractionated according to Bull et al. (2003), derivatised to trimethylsilyl ethers and analysed by gas chromatography mass spectrometry using a ThermoQuest TraceMS equipped with a non-polar fused silica capillary column (CPSil-5CB, $50 \mathrm{~m} \times 0.32 \mathrm{~mm} \times 0.12 \mu \mathrm{m}$, Varian Chrompack, Oxford, UK). Effects of dietary treatments were analyzed using analysis of variance (Genstat Release 10.1; Lawes Agricultural Trust, 2007) with 'diet' as treatment factor and 'measurement week' as block.

Results The grass silage and concentrates (for CON and GS diets) contained respectively: DM: 252, 866 and $860 \mathrm{~g} / \mathrm{kg}$; crude protein: 138, 159 and $297 \mathrm{~g} / \mathrm{kg} \mathrm{DM}$; NDF: 511, 157 and $138 \mathrm{~g} / \mathrm{kg}$ DM; starch: 0, 485 and $235 \mathrm{~g} / \mathrm{kg}$ DM; in vitro digestible organic matter: 694, 806 and $820 \mathrm{~g} / \mathrm{kg} \mathrm{DM}$. Silage $\mathrm{pH}$ was 3.81 and lactic acid $106 \mathrm{~g} / \mathrm{kg}$ DM. Despite the lower DM intakes for the GS diet, methane emission was doubled in comparison with the CON diet. The CON diet also resulted in considerably lower faecal archaeol concentrations compared to the GS diet (Table 1). No archaeol was found in any of the feed samples analysed.

Table 1 Effects of dietary treatment on feed intake, methane emission and faecal concentration of archaeol.

\begin{tabular}{lccc} 
& \multicolumn{2}{c}{ Diet: } & \multicolumn{2}{c}{ P } \\
\cline { 2 - 3 } & CON: ad libitum concentrates & GS: ad libitum grass silage & 0.824 \\
\hline Total DM intake, $\mathrm{kg} / \mathrm{d}$ & 11.43 & 9.15 & 0.022 \\
Concentrate DM intake, $\mathrm{kg} / \mathrm{d}$ & 10.18 & 2.58 (fixed) & \\
Silage DM intake, $\mathrm{kg} / \mathrm{d}$ & 1.25 (fixed) & 6.57 & 60.5 \\
Methane emission, g/d & 174 & 341 & 0.022 \\
Methane emission, g/kg DM intake & 15.0 & 37.4 & 0.005 \\
Faecal archaeol, $\mathrm{mg} / \mathrm{kg} \mathrm{DM}$ & 5.1 & 30.6 & 5.09 \\
\hline \hline
\end{tabular}

Conclusions The absence of archaeol in the feeds confirms that faecal archaeol is produced during passage through the digestive tract. Taken together with earlier observations of archaeol in faeces from ruminant species, but not in faeces from other herbivores, these results suggest a predominant origin in synthesis by rumen micro-organisms. The concentration of archaeol in the faeces studied is interpreted to reflect the size of the methanogen population in the rumen. However, further studies will be required to describe other components of this relationship, such as selective retention of Archaea in the rumen and differences in the species composition of the methanogen community (species vary in the proportions of diether and tetraether membrane lipids).

Acknowledgements The authors acknowledge the financial support of the Leverhulme Trust (F/00 182/BS) and NERC.

\section{References}

Bull, I.D., Elhmmali, M.M., Roberts, D.J., and Evershed, R.P. 2003. Archaeometry 45, 149-161.

Johnson, K.A. and Johnson, D.E. 1995. Journal of Animal Science 73, 2483-2492.

Lovett, D., Lovell, S., Stack, L., Callan, J., Finlay, M., Conolly, J. and O’Mara, F.P. 2003. Livestock Production Science 84, 135-146.

Pinares-Patiño, C.S. and Clark, H. 2008. Australian Journal of Experimental Agriculture 48, 223-229. 